\title{
THE REPEAL OF THE RETIREMENT EARNINGS TEST AND THE LABOR SUPPLY OF OLDER MEN
}

\author{
Gary V. Engelhardt and Anil Kumar* \\ CRR WP 2007-1 \\ Released: May 2007 \\ Draft Submitted: December 2006 \\ Center for Retirement Research at Boston College \\ Hovey House \\ 140 Commonwealth Avenue \\ Chestnut Hill, MA 02467 \\ Tel: 617-552-1762 Fax: 617-552-0191 \\ http://www.bc.edu/crr
}

\footnotetext{
* Gary V. Engelhardt is an associate professor of economics at Syracuse University. Anil Kumar is an economist at the Federal Reserve Bank of Dallas. The research reported herein was performed pursuant to a grant from the U.S. Social Security Administration (SSA) funded as part of the Retirement Research Consortium. The findings and conclusions are solely those of the authors and do not represent the views of SSA, any agency of the Federal Government, Syracuse University, the Federal Reserve Bank of Dallas, or Boston College.

(C) 2007, by Gary V. Engelhardt and Anil Kumar. All rights reserved. Short sections of text, not to exceed two paragraphs, may be quoted without explicit permission provided that full credit, including (C) notice, is given to the source.
} 


\title{
About the Center for Retirement Research
}

The Center for Retirement Research at Boston College, part of a consortium that includes parallel centers at the University of Michigan and the National Bureau of Economic Research, was established in 1998 through a grant from the Social Security Administration. The Center's mission is to produce first-class research and forge a strong link between the academic community and decision makers in the public and private sectors around an issue of critical importance to the nation's future. To achieve this mission, the Center sponsors a wide variety of research projects, transmits new findings to a broad audience, trains new scholars, and broadens access to valuable data sources.

\author{
Center for Retirement Research at Boston College \\ Hovey House \\ 140 Commonwealth Avenue \\ Chestnut Hill, MA 02467 \\ phone: 617-552-1762 fax: 617-552-0191 \\ e-mail: crr@bc.edu \\ www.bc.edu/crr
}

\author{
Affiliated Institutions: \\ American Enterprise Institute \\ The Brookings Institution \\ Center for Strategic and International Studies \\ Massachusetts Institute of Technology \\ Syracuse University \\ Urban Institute
}




\begin{abstract}
This paper examines the impact of the Senior Citizens Freedom to Work Act of 2000, which abolished the Social Security retirement earnings test for those aged 65-69, on the labor supply of older men using data from the 1996-2004 waves of the Health and Retirement Study (HRS). Based on reduced-form specifications, we find that the repeal of the earnings test increased labor supply on the intensive margin by $12-17 \%$, the bulk of which was concentrated among men with a high-school degree, whose labor supply rose by $19-26 \%$. We formulate a unique test for endogenous reporting of health status by examining how reported health changes with the repeal of the earnings test. We find some evidence of endogenous self-reported health status. In particular, older men were substantially less likely to have reported that health limits their ability to work after, relative to before the earnings test repeal, with the bulk of the effect concentrated among men with high-school degrees, who had the largest labor-supply response to the repeal.
\end{abstract}




\section{Introduction}

The impact of Social Security on the work incentives of older individuals is a perennial topic of interest in economics and an important factor in policy debates about the long-run solvency of the program. The key program features in this regard are the Social Security full and early retirement ages, which affect when one claims benefits (i.e., first becomes a beneficiary), and the retirement earnings test, which determines how work affects the time pattern of when benefits are received once one has claimed benefits. Prior to 2000, the earnings test reduced benefits $\$ 1$ for each $\$ 2$ of earnings above an exempt amount for beneficiaries under the full retirement age and \$1 for each \$3 of earnings above an exempt amount for those above the full retirement age but less than 70. Although any such benefit reductions are returned in an actuarially fair manner in later years, the retirement earnings test has been perceived widely as a pure tax on earnings, which, in combination with payroll and income taxation of earnings, placed very high marginal tax rates on the earnings of older workers and has led to concern by economists and policymakers that the test provides a substantial disincentive for work at older ages.

Despite a long line of research that has focused primarily on older men, using both structural and reduced-form methods, and variation in incentives induced by past changes in the earnings-test parameters, the specific role of the earnings test on work and earnings remains unclear. Some studies finding large effects, such as Friedberg (2000) and Haider and Loughran (2005), among others, and some finding small effects, such as Burtless and Moffitt (1985), Gruber and Orszag (2002), and Gustman and Steinmeier (1985), among others. ${ }^{1}$ In this paper, we use data from the 1996-2004 waves of the Health and Retirement Study (HRS) and employ a reduced-form, quasi-experimental framework to examine the impact on the labor supply of older men from the most sweeping change in the earnings test in the last two decades: the Senior Citizens Freedom to Work Act of 2000, which repealed the earnings test for beneficiaries between the full retirement age and age 70 beginning in 2000.

\footnotetext{
${ }^{1}$ Important papers in this literature include Gustman and Steinmeier (2004), Haider and Loughran (2005), Leonesio (1990), Manchester and Song (2006), Packard (1990), Pellechio (1990), Song (2004), and Tran (2004), among others.
} 
We document substantial bunching of earnings at the exempt amount for men between the full retirement age and age 70 prior to 2000 that then disappears upon the repeal of the earnings test. Furthermore, this bunching is concentrated among men with a high-school degree. At the same time, we also find a substantial increase in annual hours associated with the repeal; pooled over all men, hours rose by $12-17 \%$, with the largest effects, again, concentrated among high school graduates, whose hours rose 19-26\%. The impact of the repeal appears only on the intensive margin; there is no evidence that the repeal increased labor-force participation. The pooled labor-supply estimates imply an uncompensated labor supply (hours) elasticity with respect to the wage of $0.24-0.34$, larger than typical estimates for prime-age men, but smaller than those for women in the previous literature.

Finally, although it is widely understood that true health status is, in principle, an important determinant of the labor-supply decisions of older individuals, one difficulty, in practice, with using typical survey-based measures of self-reported health status, such as "Does your health limit your ability to work?,” that has been long recognized in the literature is that individuals may rationalize being out of the labor force by reporting they are in poor health, so that these measures may be endogenous. We utilize the rich array of information on health in the HRS and formulate a test for endogenous reporting of health status by examining how reported health changes with the repeal of the earnings test. We find some evidence of endogenous self-reported health status. In particular, older men were substantially less likely to have reported that health limits their ability to work after, relative to before, the earnings test repeal.

The remainder of the paper is organized as follows. The next section gives background on the retirement earnings test. Section 3 describes the theoretical impact of the repeal of the earnings test. Section 4 gives the results on bunching in the earnings distribution, and Section 5 describes the regression specification. Section 6 discusses the estimation results for labor supply. Section 7 presents evidence of the endogeneity of self-reported health status. There is a brief conclusion. 


\section{Background on the Earnings Test}

We begin with the basic rules for Social Security benefit computation that are relevant for the earnings test. First, in each year, earnings in covered employment up to the taxable maximum (\$90,000 in 2005) are recorded by the Social Security Administration (SSA), and then at the time the individual claims benefits, the worker's Average Indexed Monthly Earnings (AIME) are computed. The AIME is 1/12th of the average of the individual's annual covered earnings, indexed by a national wage index, where only the 35 highest years of earnings count in the average. Second, the AIME is converted into the Primary Insurance Amount (PIA), which is a basic monthly benefit, according to a progressive, three-tier benefit schedule. Third, and importantly for the earnings test, the PIA is adjusted for the age at which the benefits are claimed. In particular, if benefits are claimed at the Full Retirement Age (FRA), the monthly Social Security benefit equals the PIA. ${ }^{2}$

Table 1 shows the FRA for individuals born between 1926 and 1943, who will form the sample used in the estimation below. Traditionally, the FRA was 65, so that the month in which an individual attained the FRA always occurred in the calendar year in which the individual turned 65. However, as a result of the 1983 Amendments, the FRA was increased by two months for each year of birth from 1938-1943 and 1955-1960. For those born between 1938 and 1941, and who appear in the analysis sample described below, this means that the month in which the individual attains the FRA may fall in the calendar year in which the individual turns 65 or in the calendar year in which the individual turns 66, depending on the month of birth, which will generate an important source of identifying variation for the earnings test analysis.

Under the earnings test, reductions in benefits are made in relation to the FRA. Prior to 2000, the earnings test reduced benefits $\$ 1$ for each $\$ 2$ of annual earnings above an exempt amount, which, for example, was $\$ 8,640$ in 1997 , for beneficiaries under the

\footnotetext{
${ }^{2}$ If benefits are claimed prior to the FRA, they are decreased by an actuarial reduction factor of 5/9 of one percent per month for the first 36 months prior to the FRA and 5/12 of one percent per month for any months earlier than 36 months, where the earliest age at which benefits can be claimed is age 62, the early retirement age (ERA). If benefits are claimed after the FRA, they are increased according to the delayed retirement credit. Benefits are adjusted for marital status as well. Specifically, in the case of a married couple, the current spouse of the Social Security beneficiary is eligible to receive a dependent-spouse benefit equal to 50 percent of the beneficiary's PIA, or the spouse may claim benefits based on his or her own earnings history.
} 
FRA. For those who had reached the FRA, the earnings test reduced benefits $\$ 1$ for each $\$ 3$ of annual earnings above a somewhat higher exempt amount (e.g., \$13,500 in 1997). ${ }^{3}$ Prior to 2000, there was no earnings test for those who were 70 and older. The 2000 Act abolished the earnings test for those between the FRA and age 70 .

There are four additional rules that substantially complicate the analysis of the earnings test. First, in the calendar year in which benefits are initially claimed, the earnings test is applied on a month-by-month basis for the months in which the individual receives benefits and depends on whether monthly earnings after claiming exceed the monthly exempt amount, which is $1 / 12^{\text {th }}$ of the annual exempt amount. ${ }^{4}$ If earnings exceed the monthly exempt amount, then benefits are not paid for that month. Second, in the calendar year in which the beneficiary turns 70 , the earnings test is applied only to earnings in the months the beneficiary was 69. Third, the 2000 Act created a separate earnings test category for the calendar year in which the individual attains the FRA. This test applies until the month in which the FRA is reached, after which earnings no longer affect benefit receipt. Each of these special rules implies that even individuals who have the same birth year will be exposed to the earnings test for different lengths of time, according to their month of birth. This generates important sources of variation that are exploited below in the identification strategy. Finally, income from self-employment, though subject to the test, is treated differently than wage income. In particular, selfemployment income is counted in the year it is received, rather than the year it is earned. This means the self-employed have the ability to smooth earnings across years potentially to lessen the burden of the earnings test, in a way that those with wage income cannot.

\section{Theoretical Impact of the Repeal of the Earnings Test}

As has been long understood in the literature, there are three broad theoretical partial-equilibrium responses to have been expected from the repeal of the earnings test from standard models of labor supply when the test is considered a pure tax on earnings.

\footnotetext{
${ }^{3}$ Although the earnings test is widely perceived as a pure tax on earnings, any lost benefits are returned to the beneficiary in later years in accordance with the actuarial adjustment and delayed retirement credit, so that, overall, the earnings test is designed to be actuarially fair. In addition, any annual amounts earned under the earnings test are used to recalculate the 35 highest years of earnings for the basic benefit calculation described above, so that earnings under the test can directly increase benefits in all future years.

${ }^{4}$ The monthly test for self-employment income is expressed in terms of hours and degree of effort, rather than dollars of earnings.
} 
First, there should have been intratemporal, intensive-margin responses for beneficiaries already in the labor force at the time of the law change due to income and substitution effects induced by the repeal. Second, there could have been an extensive margin response if there were fixed costs to working, minimum hours' constraints, or other labor-market rigidities that affected older workers. ${ }^{5}$ Finally, there could have been an intertemporal response if individuals shifted their labor supply from years of high to years of low taxation.

To help motivate the empirical analysis, Figure 1 illustrates in more detail the intratemporal intensive margin response, which has been the focus of attention in many previous studies. The bold line represents the budget constraint under the earnings test faced by those between the FRA and age 70 prior to the 2000 Act, where $\tilde{H}_{1}$ is the threshold number of hours (at a given wage rate $w$ ) at which the annual exempt amount is reached and after which additional earnings reduce the receipt of benefits, resulting in a convex kink, $k_{1}$, in the budget constraint. The point $\tilde{H}_{2}$ is the threshold number hours at which benefits have been reduced to zero. Between $\tilde{H}_{1}$ and $\tilde{H}_{2}$ hours, the individual faces an effective wage rate of $(2 / 3) w$, and, for hours greater than $\tilde{H}_{2}$, the individual faces an effective wage rate of $w$, resulting in a non-convex kink, $k_{2}$, at $\tilde{H}_{2}$. The dashed line shows the budget constraint after the repeal.

There are two important theoretical predictions from the figure. First, prior to the repeal, there should have been bunching of earnings at the exempt amount associated with the convex kink, $k_{1}$. Second, the repeal likely had differential effects on hours and earnings by skill level. For those who located on the first segment ( 0 to $\left.\tilde{H}_{1}\right)$, the repeal did not change the budget set, and, therefore should not have changed their labor supply. Because the exempt amount in 1999—-the last year before the law change—was $\$ 15,500$, those locating on the first segment were likely to have been low-skill workers, who, naturally, had low wage rates and for whom even full-time work (i.e., 2,000 hours/year) would have placed them on the first segment. For those located on the third segment, such as high-skill workers, for whom the earnings test was inframarginal, the repeal

\footnotetext{
${ }^{5}$ See, for example, Altonji and Paxson (1988), Cogan (1981), Card (1990), Hausman (1980), and Hurd (1996).
} 
induced an income effect, and their hours and earnings should have fallen as a result. For those who located on the second segment, most likely moderate-skill workers, for whom the test had a marginal effect on the net wage rate, the repeal should have induced income and substitution effects, the relative strength of which would have determined the hours’ response.

\section{The Repeal of the Earnings Test and the Distribution of Earnings}

We begin the empirical analysis by evaluating the first prediction: the bunching of earnings at the exempt amounts. The sample consists of all men age 62-72, from the 1926-43 birth cohorts, from the 1996, 1998, 2000, 2002, and 2004 waves of the HRS, from which we exclude two types of person-year observations: those with selfemployment income, because the earnings test rules for such income differ from wage income, and those based on proxy interviews. Overall, this sample consists of 8,653 person-year observations based on 3,839 men. Selected descriptive statistics are shown in Table 2.

Figure 2A shows the distribution of real earnings (in 2001 dollars) taken from the income section of the HRS survey relative to the exempt amount in intervals of $\$ 1,000$ for men 65-70 years old and in the labor force prior to the repeal. ${ }^{6}$ The value of zero on the horizontal axis indicates that annual earnings equaled the exempt amount; a negative value means that earnings were less than the exempt amount; a positive value means that earnings were greater than the exempt amount. The figure shows that the bulk of earnings were below the exempt amount, and, more specifically, bunching at the exempt amount.

In comparison, Figure 2B shows the real earnings distribution after the repeal. For this figure, earnings are shown relative to a counterfactual exempt amount, namely the nominal 1999 exempt amount $(\$ 15,500)$ indexed by the national wage index for the years 2000-2003 and then deflated into real terms. There is no evidence of bunching after the repeal. This suggests that the earnings test for those above the FRA was binding

\footnotetext{
${ }^{6}$ Like other household surveys, income measures in the HRS refer to the calendar year prior to the survey year, so that these earnings refer to 1995, 1997, and 1999, respectively. Nominal earnings were deflated into real values using the all-items CPI. For the purposes of graphical exposition, earnings shown are limited to those under the FICA cap (e.g., \$80,400 in \$2001), although this does not affect the implications for bunching.
} 
prior to the repeal. ${ }^{7}$ This conclusion is bolstered by Figures 3A and 3B, which show the real earnings distributions for a comparison group of men-those in the labor force, aged 62 to 64 , for whom the earnings test was unchanged-before and after 2000, respectively. For this younger group of men, the real earnings distributions are very similar before and after the law change, both showing evidence of bunching at the exempt amount.

\section{Regression Framework and Identification}

We begin with a simple difference-in-difference analysis of the impact of the repeal on labor supply, shown in Table 3. The treatment group consists of men who attained their $65^{\text {th }}-70^{\text {th }}$ birthdays during the calendar year-referred to throughout the analysis as "65-70 year olds"-and, hence, were subject to the earnings test for part or all of the calendar year before, but not after, the repeal. The control group consists of 62-64 and 71-72 year old men, whose status under the earnings test did not change because of the repeal. In the first row, the difference-in-difference in annual hours, defined as the sum of hours on the main and second (if any) jobs, is 153 hours, and, with a standard error of 53, is statistically different than zero. Compared to the sample mean of 520 hours, this represents a $29 \%$ increase in hours of labor supplied due to the earnings test repeal.

Because there are a variety of ways in which older individuals characterize their labor market attachment (Gustman, Mitchell, and Steinmeier, 1995), the remaining rows of the table examine three alternative, discrete measures of labor supply: whether the individual does any work for pay, works full-time, and whether the individual reports in the survey that he is retired. The difference-in-difference estimates for these measures are statistically different than zero and consistent with the large labor-supply response found for hours. Relative to the control group, men aged 65 to 70 working for pay rose 5.6 percentage points, or $18 \%$ (relative to the mean). Those engaged in full-time work rose by 7.3 percentage points, or 39\%. Finally, those who reported being retired fell by 4.4 percentage points, or $6.7 \%$.

\footnotetext{
${ }^{7}$ This finding is qualitatively unchanged if the counterfactual exempt amount is based on the amounts legislated in the 1996 Act (i.e., \$17,000, \$25,000, \$30,000, \$30,720, in 2000-2003 in nominal terms, respectively.)
} 
While the simple analysis in Table 3 suggests that the repeal of the earnings test had important effects on the labor supply of older men, it has two important limitations. First, it used the variation in work incentives from the repeal in only a very coarse way. Second, it did not take into account other factors that may have affected labor supply and may have been correlated with the repeal.

To control for these other factors and better exploit the legislative variation, we expand the analysis into a more sophisticated regression framework. Specifically, we begin with a basic model that is similar to reduced-form specifications estimated in previous studies, such as Gruber and Orszag (2003):

$$
Y_{i t}=\kappa+\beta X_{i t}+\theta \text { MarStat }_{i t}+\delta \text { Age }_{i t}+\gamma Z_{i}+\pi \text { Interview }_{i t}+\tau_{t}+u_{i t},
$$

where $i$ and $t$ index the individual and calendar year, respectively, $Y$ represents one of the labor-supply measures, $\kappa$ is a constant, MarStat controls for marital status, Age is measured in years, Interview is the number of months (since January, 1960) in which that wave's interview took place, $\tau$ is a set of year effects, and $Z$ is a vector of timeinvariant characteristics that includes race, educational attainment, and veteran status.

The key explanatory variable, $X$, is the fraction of the calendar year that the individual is subject to the earnings test based on the year and month of birth. Specifically, because the repeal treated the earnings of individuals of the same ages (6570) differently in different calendar years, the 2000 Act induced age-by-time, or year-ofbirth, variation in exposure to the earnings test. This is illustrated in Table 4, which depicts the sources of variation due to the repeal for the calendar years covered by the HRS and the years of birth used in this study for a man who claims benefits on his $62^{\text {nd }}$ birthday. Age refers to the age attained on the birthday in that calendar year.

Beneficiaries who fall into cells highlighted in yellow and orange were unaffected by the law change: yellow indicates the beneficiary was subject to the earnings test for the entire calendar year; orange indicates that the beneficiary was subject to the earnings test for only part of the year, for example, only beginning with the month of birth in the year he turns 62 and ending in the month of birth in the year he turns 70. The year-of-birth variation from the repeal is shown by the rectangle shaded in green (light and dark), blue, and purple, men aged 65-70 after the law change. For example, beneficiaries in the 1929 cohort (in bold) were subject to the earnings test every year from ages 62-70 under the 
pre-2000 law. Beneficiaries born five years later, in 1934 (also in bold) were subject to the earnings test in the same manner up through age 65 , but not for ages 66-70 because of the repeal.

The table also illustrates the variation in exposure due to the month of birth, which has three sources. First, prior to the repeal, beneficiaries who turned 70, and fall into cells highlighted in orange, were subject to the earnings test for only part of the year, ending in the month of birth in the year they turned 70. For example, those born in April were subject to the test for 3 months, while those born in October were subject to the test for 9 months. After the repeal, beneficiaries who turned 70 were not subject to the test in any month of that year. These cells are highlighted in purple in the table. Second, prior to the repeal, all beneficiaries in the year they turned 65 were subject to the earnings test for the entire year, regardless of month of birth, but after the repeal, similar beneficiaries were subject to the earnings test until their birth month, generating within-year-of-birth variation in exposure. These cells are highlighted in light green in the table. Finally, after the repeal, the earnings test is applied until the beneficiary reaches the full retirement age, but, as documented in Table 1, that age has been increased two months per birth year, for each birth year beginning with 1938. This means that, beginning with the 1938 cohort, beneficiaries born in later months of the year were exposed to the earnings test for the entire calendar year they turn 65 and part of the calendar year they turn $66 .{ }^{8}$ These cells are highlighted in dark green in the table. To summarize, the repeal induced acrosscalendar-year variation in exposure to the earnings test that varied by year of birth, the impact of which was differential by month of birth as well.

We construct the exposure variable, $X$, to capture these sources of variation. Specifically, let $x_{c m k t}$ be the fraction of the calendar year $t$ a beneficiary who was born in year $c$, month $m$, and claimed benefits at age $k$, was exposed to the earnings test based solely on the legislative variation in earnings-test rules. Because the earnings test may have affected claiming behavior, we do not want to use the value of $x$ associated with the individual's actual claiming age. Instead, we take a weighted average of $x$, weighting the claiming-age-specific exposure by the distribution of claiming ages for the 1926 cohort

\footnotetext{
${ }^{8}$ For example, someone born in December, 1937, was exposed for all of year turning age 65, but none of the year turning age 66, while someone born in December, 1938, was exposed all of the year turning age 65 and the first two months of the year turning age 66.
} 
taken from the various issues of the Annual Statistical Supplement to yield a claimingage-weighted exposure, $X$. That is, let $\operatorname{Pr}\left(R_{1916 k}\right)$ be the probability of claiming retirement benefits at age $k$ for the 1926 cohort; then the key explanatory variable is $X \equiv \sum_{k=62}^{72} \operatorname{Pr}\left(R_{1926 k}\right) \cdot\left[x_{c m k t}\right]$,

and ranges from zero to one.

Because the HRS provides panel data two years apart, we estimate the model in first differences,

$\Delta Y_{i t}=\alpha+\beta \Delta X_{i t}+\theta \Delta$ MarStat $_{i t}+\pi \Delta$ Interview $_{i t}+\gamma_{t}+v_{i t}$,

where the dependent variable, $\Delta Y_{i t} \equiv Y_{i t}-Y_{i t-2}$, measures the change in the outcome measure in the last 2 years, $\alpha \equiv 2 \delta, v \equiv \Delta u, \gamma \equiv \Delta \tau, \Delta$ MarStat indicates a change in marital status in the last 2 years, and $\Delta$ Interview indicates the number of months elapsed since the last interview. The key identifying assumption is that the variation in $\Delta X$ induced by the repeal of the earnings test is plausibly exogenous with respect to the trajectory of the unobserved variable(s), including any measurement error, embodied in $v$. The key parameter is $\beta$, which measures the impact of the earnings test on the laborsupply outcome. For example, if the retirement earnings test reduced hours then, $\beta<0$. Likewise, the impact of the repeal of the test is measured as $-\beta$.

\section{Estimation Results}

Table 5 shows the ordinary least squares (OLS) estimates of $-\beta$ in (3) for the four measures of labor supply. Each cell in the table gives a parameter estimate, $-\widehat{\beta}$, from a separate regression. The standard error of $\widehat{\beta}$, which was clustered by individual, is shown in parentheses. ${ }^{9}$ The sample size (number of first-differenced person-year

\footnotetext{
${ }^{9}$ Because the exposure variable varies by calendar year, year and month of birth, and there are repeated observations on individuals, the standard errors, in principle, should be multi-way clustered (Cameron, Gelbach, and Miller, 2006). However, in practice, using the STATA ado-file posted on Miller's website, there was no bias in the standard errors presented in Table 5 relative to those clustered by person and month of birth. In fact, the two-way clustered standard errors were somewhat smaller than those presented in the table.
} 
observations) is shown in square brackets, and the sample mean of the outcome is shown in curly brackets.

The first row presents estimates where the outcome is annual hours. For all men (row 1 , column 1 ), $-\widehat{\beta}=204$, with a standard error of 18 , which indicates that the repeal of the earnings test increased labor supply of older men by 204 hours per year, and this effect is statistically significant. Relative to the sample mean of 520 hours, the repeal increased annual hours by 39\%, which is a substantial impact.

Because the repeal induced year-of-birth variation in incentives to work, and there may have been important, independent year-of-birth trends in labor supply, column 2 presents estimates in which each regression includes a full set of year-of-birth dummies, so that the estimates are identified off of the month-of-birth variation described above. This greatly reduces the estimated impact of the repeal. Now, (row 1, column 2), $-\widehat{\beta}=68$, with a standard error of 23 , which indicates that, relative to the sample mean of 520 hours, the repeal increased annual hours by $13 \%$.

For the specifications in columns 3 and 4, 2\% of the sample has been trimmed from each tail of the change-in-hours' distribution in order to reduce the impact of measurement error in reported hours. Without year-of-birth effects (row 1, column 3), $-\widehat{\beta}=152$, which relative to the comparable untrimmed estimate in column 1 , indicates that trimming reduces the estimated hours' response by about 25\%. With year-of-birth effects (row 1 , column 4 ), $-\widehat{\beta}=48$, and is statistically significant, so that the repeal increased annual hours by $9 \%$ relative to the mean.

Columns 5-8 check the robustness of these findings to both measurement error and long-run trends in labor supply employing four-year rather than two-year differencing to the specifications in columns 1-4 (Griliches and Hausman, 1986). These specifications indicate that the earnings-test repeal raised labor supply by 59-85 hours per year, which represented a $12-17 \%$ increase relative to the mean. Under the assumption that older men view the earnings test as a pure tax on earnings, these estimates translate into uncompensated labor-supply elasticities of 0.24-0.34-higher than typical elasticities found for prime-age men, but lower than many estimates for prime-age women (Blundell and Macurdy, 1999). 
The remaining rows in the table examine the impact of the repeal on the three alternative measures of labor supply. For the richer specifications in columns 2 and 6, respectively, the repeal did not increase labor force participation, as measured by doing any work or being retired, but did increase the incidence of full-time work. Specifically, the likelihood of full-time work rose 2.2-2.7 percentage points, or 12-15\% relative to the sample mean full-time participation, which is consistent with the hours' response documented above.

Table 6 presents estimates that test the theoretical prediction that the repeal had differential effects on hours by skill level: the repeal was more likely to have been inframarginal for low- and high-skill workers, but marginal for moderate-skill workers. To do so, the specification is estimated separately by educational attainment group-high school dropout, high school degree, some college, and college degree-which proxies for skill level. The results for hours, on both the trimmed and untrimmed samples, are consistent with the prediction, namely there is no statistically significant impact of the repeal on hours for high school dropouts and those with college degrees. Instead, the bulk of the labor-supply response is centered on high-school graduates. For example, for the trimmed sample in row 3, columns 2 and 4, the repeal raised labor supply by 99 and 129 hours per year, or 19\% and 26\%, respectively, for high school graduates. Both estimates are statistically different than zero. In addition, the repeal was associated with an increase of around 2.2 percentage points, or $12 \%$ (relative to the mean), in the likelihood of full-time work in column 5 (row 1). Again, this effect was concentrated primarily on men with a high school degree (row 3), for whom the incidence of full-time work rose by about $19 \%$ (column 5) to 23\% (column 6). Finally, Table 7 indicates that there is little evidence that the repeal increased labor force participation, as measured by doing any work and being retired.

To summarize, the repeal of the earnings test had a marked impact on the labor supply of older men, coming through an intensive-margin response. Across all men, the repeal raised hours and full-time work by around $12 \%$. However, almost all of this effect was concentrated among high school graduates, for whom hours and full-time work increased by around 23\%. 
To help corroborate these findings, we split the sample into two groups, those with a high-school degree and all others, and re-draw the earnings distribution figures for each group for 65-70 year olds. Figure 4A indicates a substantial amount of bunching at the exempt amount for those with high school degrees before the repeal that disappears in Figure 4B after the repeal. Figure 5A shows bunching for all other education groups, which is diminished in Figure 5B, but it is much less pronounced than for those with a high-school degree. These patterns are consistent with the labor-supply findings that the bulk of the impact of the earnings-test repeal was on high school graduates.

\section{A Test for the Endogeneity of Self-Reported Health Status}

Although it is widely understood that true health status is, in principle, an important determinant of the labor-force participation decision of older individuals, one difficulty, in practice, with using typical survey-based measures of self-reported health status, such as "Does your health limit your ability to work?” and "Would you say your health is excellent, very good, good, fair or poor?," that has been long recognized in the literature is that individuals may rationalize being out of the labor force by reporting they are in poor health, so that these measures may be endogenous. Because the repeal of the earnings test generated plausibly exogenous variation in incentives to work, the rich array of information on health in the HRS provides a unique opportunity to test for endogenous reporting of health status.

Specifically, columns 1 and 2 of Table 8 present estimates of $-\beta$ in (3) for the two self-reported measures of health that have been identified in the previous literature as being susceptible to rationalization and endogeneity: whether the individual reported that his/her health limited the ability to work and whether in fair/poor health. For all men (row 1), the repeal is associated with a decrease of 2.5-3.7 percentage points (or 9-13\%, relative to the mean) in the likelihood that men say their health limited their ability to work, and these effects were statistically significant. The remaining rows in the table repeat the estimation for each education group. Remarkably, the bulk of this effect is concentrated on those with high-school degrees, precisely the group whose labor supply responded the most to the repeal. For these men, the repeal decreased by 5.4 to 8.1 percentage points, or $19-31 \%$ relative to the mean, the likelihood that these men said that 
health limited their ability to work. These effects were statistically significant. Although the estimates in columns 3 and 4 indicate no overall impact of the repeal on whether men report themselves in fair or poor health, they do indicate an effect for men with highschool degrees: a decrease in the likelihood of self-assessed fair or poor health of 3.3 to 3.8 percentage points, or $11-12 \%$ relative to the mean.

\section{Conclusion}

This paper examined the impact of the Senior Citizens Freedom to Work Act of 2000, which abolished the Social Security retirement earnings test for those aged 65-70, on the labor supply of older men using data from the 1996-2004 waves of the Health and Retirement Study (HRS). Based on reduced-form specifications, we found that the repeal

of the earnings test increased labor supply on the intensive margin by $12-17 \%$, the bulk of which was concentrated among men with a high-school degree, whose labor supply rose by $19-26 \%$. We formulated a unique test for endogenous reporting of health status by examining how reported health changes with the repeal of the earnings test and found some evidence of endogenous self-reported health status. In particular, older men were substantially less likely to have reported that health limits their ability to work after relative to before the earnings test repeal, with the bulk of the effect concentrated among men with high-school degrees, who had the largest labor-supply response to the repeal. 


\section{References}

Altonji, Joseph G., and Christina H. Paxson. "Labor Supply Preferences, Hours Constraints, and Hours-Wage Trade-Offs,” Journal of Labor Economics 6 (1988): 254276.

Blundell, Richard, and Thomas MaCurdy, "Labor Supply: A Review of Alternative Approaches,” in Orley Ashenfelter and David Card, eds., Handbook of Labor Economics, Volume 3A, (Amsterdam: North Holland), 1999, pp. 1559-1695.

Burtless, Gary, and Robert A. Moffitt, “The Joint Choice of Retirement Age and PostRetirement Hours of Work,” Journal of Labor Economics 3 (1985): 209-236.

Cameron, A. Colin, Jonah B. Gelbach, and Douglas L. Miller, "Robust Inference with Multi-Way Clustering,” NBER Technical Working Paper No. 327, 2006.

Card, David, "Labor Supply with a Minimum Hours Threshold,” Carnegie-Rochester Conference Series on Public Policy 33 (1990): 137-168.

Cogan, John F., “Fixed Costs and Labor Supply,” Econometrica 49 (1981): 945-963.

Friedberg, Leora, "The Labor Supply Effects of the Social Security Earnings Test," Review of Economics and Statistics 82:1 (2000): 48-63.

Gruber, Jonathan, and Peter Orszag, "Does the Social Security Earnings Test Affect Labor Supply and Benefits Receipt?” National Tax Journal 56:4 (2003): 755-773.

Griliches, Zvi, and Jerry A. Hausman, “Errors in Variables in Panel Data,” Journal of Econometrics 31 (1986): 93-118.

Gustman, Alan L., and Thomas L. Steinmeier, "The 1983 Social Security Reforms and Labor Supply Adjustments of Older Individuals in the Long Run,” Journal of Labor Economics 3:2 (1985): 237-253.

Gustman, Alan L., and Thomas L. Steinmeier, “The Social Security Retirement Earnings Test, Retirement and Benefit Claiming,” NBER Working Paper No. 10905, 2004.

Gustman, Alan L., Olivia S. Mitchell, and Thomas L. Steinmeier, "Retirement Measures in the Health and Retirement Study,” Journal of Human Resources 30 (1995): S57-S83.

Haider, Steven J., and David S. Loughran, "Do the Elderly Respond to Taxes on Earnings? Evidence from the Social Security Earnings Test,” Mimeo., Michigan State University, 2005.

Hausman, J. (1980), “The Effect of Wages, Taxes and Fixed Costs on Women's Labor Force Participation.” Journal of Public Economics 14: 161-194. 
Hurd, Michael. 1996. "The Effect of Labor Market Rigidities on the Labor Force Behavior of Older Workers," in Wise, David (ed.), Advances in the Economics of Aging. Chicago: University of Chicago Press, 11-58.

Leonesio, Michael V., "Effects of the Social Security Earnings Test on the Labor Market Activity of Older Americans: A Review of the Evidence," Social Security Bulletin 53 (1990): 2-21.

Manchester, Joyce, and Jae Song, "New Evidence on Earnings and Benefit Claims Following Changes in the Retirement Earnings Test in 2000," Social Security Administration Office of Research, Evaluation, and Statistics Working Paper no. 107, 2006.

Packard, Michael D., "The Earnings Test and the Short-Run Work Response to Its Elimination,” Social Security Bulletin 53:9 (1990): 2-16.

Pellechio, Anthony, “The Social Security Earnings Test, Labor Supply Distortions, and Foregone Payroll Tax Revenues.” Journal of Public Economics 24:2 (1980).

Song, Jae G., "Evaluating the Initial Impact of Eliminating the Retirement Earnings Test,” Social Security Bulletin 65:1 (2004): 1-15.

Tran, Bac. 2004. "The Effect of the Repeal of the Retirement Earnings Test on the Labor Supply of Older Workers.” Mimeo., University of Maryland. 
Table 1. Full Retirement Age for Individuals Born 1926-43

(1)

(2)

(3)

(4)

\begin{tabular}{lcccc} 
Year of Birth & $\begin{array}{c}\text { Attain Age } \\
62 \text { in }\end{array}$ & $\begin{array}{c}\text { Attain Age } \\
65 \text { in }\end{array}$ & $\begin{array}{c}\text { Attain Age } \\
70 \text { in }\end{array}$ & Full Retirement Age \\
\hline 1926 & 1988 & 1991 & 1996 & 65 years \\
1927 & 1989 & 1992 & 1997 & 65 years \\
1928 & 1990 & 1993 & 1998 & 65 years \\
1929 & 1991 & 1994 & 1999 & 65 years \\
1930 & 1992 & 1995 & 2000 & 65 years \\
1931 & 1993 & 1996 & 2001 & 65 years \\
1932 & 1994 & 1997 & 2002 & 65 years \\
1933 & 1995 & 1998 & 2003 & 65 years \\
1934 & 1996 & 1999 & 2004 & 65 years \\
1935 & 1997 & 2000 & 2005 & 65 years \\
1936 & 1998 & 2001 & 2006 & 65 years \\
1937 & 1999 & 2002 & 2007 & 65 years \\
1938 & 2000 & 2003 & 2008 & 65 years, 2 months \\
1939 & 2001 & 2004 & 2009 & 65 years, 4 months \\
1940 & 2002 & 2005 & 2010 & 65 years, 6 months \\
1941 & 2003 & 2006 & 2011 & 65 years, 8 months \\
1942 & 2004 & 2007 & 2012 & 65 years, 10 months \\
1943 & 2005 & 2008 & 2013 & 66 years \\
\hline \multicolumn{2}{l}{ Note: Taken from the 2005 Annual Statistical Supplement, Table 2.A17.1. } \\
\hline \multicolumn{5}{r}{} \\
\hline
\end{tabular}


Table 2. Means of Selected Variables for the Sample of Men Aged 62-72, Based on the 1996-2004 Waves of the HRS, Standard Deviations in Parentheses

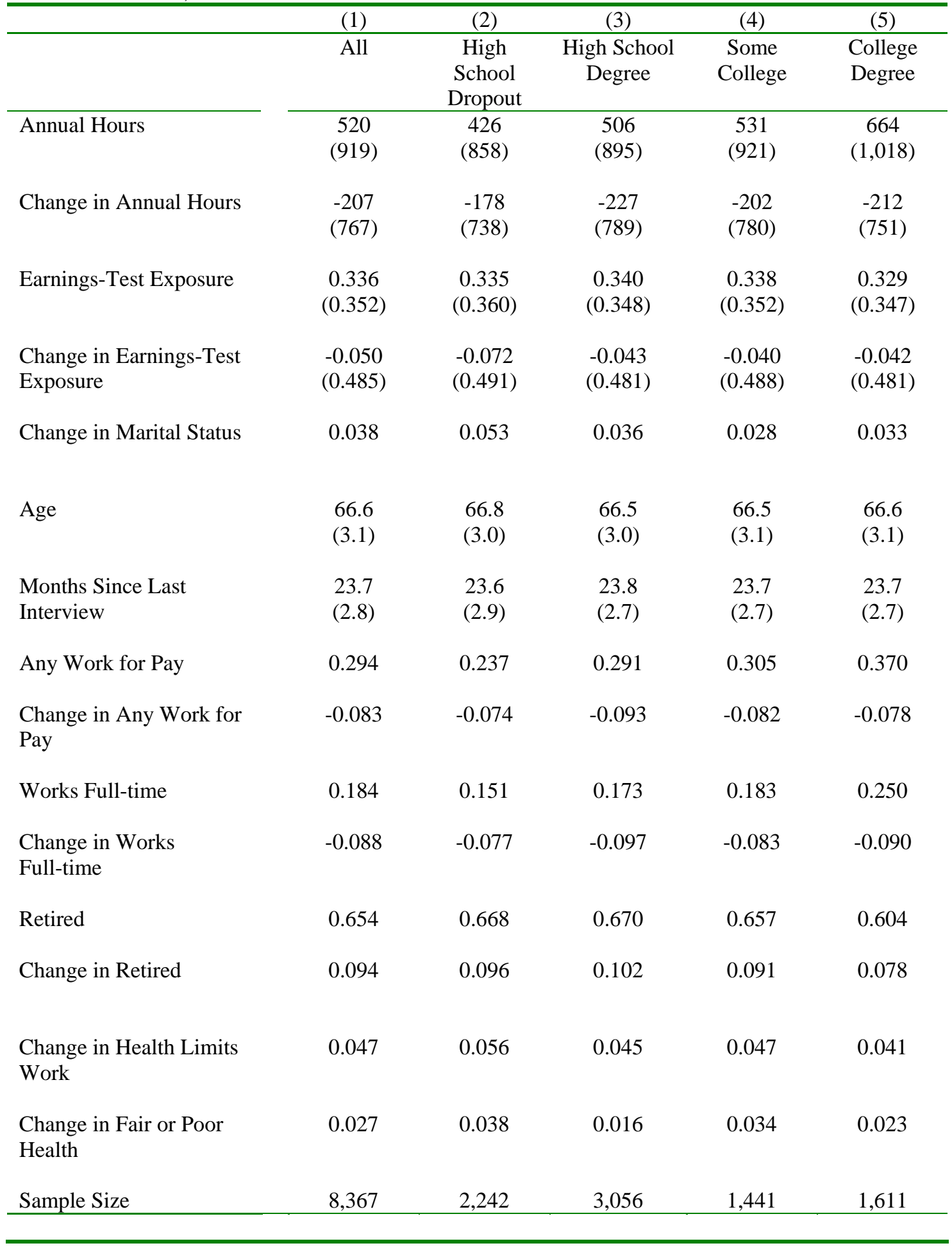


Table 3. Difference-in-Difference Estimates of the Impact of the Repeal of the Retirement Earnings Test on Various Measures of Labor Supply, in which Men Aged 65-70 are the Treatment Group and Men Aged 62-64 and 71-72 are the Control Groups, Based on the 1996-2004 Waves of the HRS, Standard Errors in Parentheses, Sample Mean in Curly Brackets

\begin{tabular}{lc}
\hline Labor Supply Measure & $\begin{array}{c}\text { Difference-in } \\
\text { Difference Estimate }\end{array}$ \\
\hline Annual Hours & 153 \\
& $\{53)$ \\
& $520\}$ \\
Any Work for Pay & 0.056 \\
& $(0.026)$ \\
& $\{0.308\}$ \\
Works Full-time & 0.073 \\
& $(0.022)$ \\
Retired & $0.186\}$ \\
& -0.044 \\
& $(0.026)$ \\
& $\{0.629\}$ \\
\hline
\end{tabular}


Table 4. Illustration of the Variation in Exposure to the Earnings Test Induced by the Repeal for a Man who Claimed Benefits on His $62^{\text {nd }}$ Birthday

\begin{tabular}{|c|c|c|c|c|c|c|c|c|c|c|c|c|c|c|c|}
\hline Age/Year & 1991 & 1992 & 1993 & 1994 & 1995 & 1996 & 1997 & 1998 & 1999 & 2000 & 2001 & 2002 & 2003 & 2004 & 2005 \\
\hline 62 & 1929 & 1930 & 1931 & 1932 & 1933 & 1934 & 1935 & 1936 & 1937 & 1938 & 1939 & 1940 & 1941 & 1942 & 1943 \\
\hline 63 & 1928 & 1929 & 1930 & 1931 & 1932 & 1933 & 1934 & 1935 & 1936 & 1937 & 1938 & 1939 & 1940 & 1941 & 1942 \\
\hline 64 & 1927 & 1928 & 1929 & 1930 & 1931 & 1932 & 1933 & 1934 & 1935 & 1936 & 1937 & 1938 & 1939 & 1940 & 1941 \\
\hline 65 & 1926 & 1927 & 1928 & 1929 & 1930 & 1931 & 1932 & 1933 & 1934 & 1935 & 1936 & 1937 & 1938 & 1939 & 1940 \\
\hline 66 & 1925 & 1926 & 1927 & 1928 & 1929 & 1930 & 1931 & 1932 & 1933 & 1934 & 1935 & 1936 & 1937 & 1938 & 1939 \\
\hline 67 & 1924 & 1925 & 1926 & 1927 & 1928 & 1929 & 1930 & 1931 & 1932 & 1933 & 1934 & 1935 & 1936 & 1937 & 1938 \\
\hline 68 & 1923 & 1924 & 1925 & 1926 & 1927 & 1928 & 1929 & 1930 & 1931 & 1932 & 1933 & 1934 & 1935 & 1936 & 1937 \\
\hline 69 & 1922 & 1923 & 1924 & 1925 & 1926 & 1927 & 1928 & 1929 & 1930 & 1931 & 1932 & 1933 & 1934 & 1935 & 1936 \\
\hline 70 & 1921 & 1922 & 1923 & 1924 & 1925 & 1926 & 1927 & 1928 & 1929 & 1930 & 1931 & 1932 & 1933 & 1934 & 1935 \\
\hline 71 & 1920 & 1921 & 1922 & 1923 & 1924 & 1925 & 1926 & 1927 & 1928 & 1929 & 1930 & 1931 & 1932 & 1933 & 1934 \\
\hline 72 & 1919 & 1920 & 1921 & 1922 & 1923 & 1924 & 1925 & 1926 & 1927 & 1928 & 1929 & 1930 & 1931 & 1932 & 1933 \\
\hline
\end{tabular}


Table 5. Parameter Estimates of the Impact of the Repeal of the Retirement Earnings Test on Various Measures of the Labor Supply of Men Aged 6272, Based on the 1996-2004 Waves of the HRS, Standard Errors in Parentheses, Sample Size in Square Brackets, Sample Mean of the Labor-Supply Measures in Curly Brackets

\begin{tabular}{|c|c|c|c|c|c|c|c|c|}
\hline Outcome & $(1)$ & $(2)$ & $(3)$ & $(4)$ & $(5)$ & $(6)$ & $(7)$ & (8) \\
\hline $\begin{array}{l}\text { Annual Hours, } \\
\text { Current Year }\end{array}$ & $\begin{array}{c}204 \\
(18) \\
{[\mathrm{N}=8,367]} \\
\{520\}\end{array}$ & $\begin{array}{c}68 \\
(23) \\
{[\mathrm{N}=8,367]} \\
\{520\}\end{array}$ & $\begin{array}{c}152 \\
(17) \\
{[\mathrm{N}=8,206]} \\
\{530\}\end{array}$ & $\begin{array}{c}48 \\
(21) \\
{[N=8,206]} \\
\{530\}\end{array}$ & $\begin{array}{c}85 \\
(26) \\
{[N=5,631]} \\
\{507\}\end{array}$ & $\begin{array}{c}76 \\
(28) \\
{[N=5,631]} \\
\{507\}\end{array}$ & $\begin{array}{c}72 \\
(23) \\
{[N=5,519]} \\
\{513\}\end{array}$ & $\begin{array}{c}59 \\
(25) \\
{[N=5,519]} \\
\{513\}\end{array}$ \\
\hline $\begin{array}{l}\text { Any Work in } \\
\text { Current Year }\end{array}$ & $\begin{array}{c}0.062 \\
(0.009) \\
{[N=8,631]} \\
\{0.309\}\end{array}$ & $\begin{array}{c}0.014 \\
(0.013) \\
{[N=8,631]} \\
\{0.309\}\end{array}$ & -- & -- & $\begin{array}{c}0.022 \\
(0.014) \\
{[\mathrm{N}=5,871]} \\
\{0.299\}\end{array}$ & $\begin{array}{c}0.018 \\
(0.014) \\
{[\mathrm{N}=5,871]} \\
\{0.299\}\end{array}$ & -- & -- \\
\hline $\begin{array}{l}\text { Says Currently } \\
\text { Working } \\
\text { Full-time }\end{array}$ & $\begin{array}{c}0.085 \\
(0.008) \\
{[\mathrm{N}=8,653]} \\
\{0.191\}\end{array}$ & $\begin{array}{c}0.022 \\
(0.011) \\
{[\mathrm{N}=8,653]} \\
\{0.191\}\end{array}$ & -- & -- & $\begin{array}{c}0.032 \\
(0.012) \\
{[N=5,875]} \\
\{0.186\}\end{array}$ & $\begin{array}{c}0.027 \\
(0.013) \\
{[N=5,875]} \\
\{0.186\}\end{array}$ & -- & -- \\
\hline $\begin{array}{l}\text { Says Currently } \\
\text { Retired }\end{array}$ & $\begin{array}{c}-0.062 \\
(0.010) \\
{[\mathrm{N}=8,653]} \\
\{0.639\}\end{array}$ & $\begin{array}{c}-0.001 \\
(0.014) \\
{[N=8,653]} \\
\{0.639\}\end{array}$ & -- & -- & $\begin{array}{c}-0.011 \\
(0.015) \\
{[N=5,875]} \\
\{0.650\}\end{array}$ & $\begin{array}{c}-0.007 \\
(0.016) \\
{[N=5,875]} \\
\{0.650\}\end{array}$ & -- & -- \\
\hline $\begin{array}{l}\text { Periodicity of } \\
\text { Differences }\end{array}$ & 2-Year & 2-Year & 2-Year & 2-Year & 4-Year & 4-Year & 4-Year & 4-Year \\
\hline $\begin{array}{l}\text { Year-of-Birth } \\
\text { Effects } \\
\text { Included? }\end{array}$ & No & Yes & No & Yes & No & Yes & No & Yes \\
\hline $\begin{array}{l}\text { Trimmed } \\
\text { Sample? }\end{array}$ & No & No & Yes & Yes & No & No & Yes & Yes \\
\hline
\end{tabular}


Table 6. Parameter Estimates by Education Group of the Impact of the Repeal of the Retirement Earnings Test on the Labor Supply of Men Aged 62-72, Based on the 1996-2004 Waves of the HRS, Standard Errors in Parentheses, Sample Size in Square Brackets, Sample Means of Labor-Supply Measures in Curly Brackets

\begin{tabular}{|c|c|c|c|c|c|c|}
\hline & (1) & (2) & (3) & (4) & (5) & (6) \\
\hline $\begin{array}{l}\text { Education } \\
\text { Group }\end{array}$ & \multicolumn{4}{|c|}{ Annual Hours } & \multicolumn{2}{|c|}{ Works Full-Time } \\
\hline All & $\begin{array}{c}68 \\
(23) \\
{[N=8,367]} \\
\{520\}\end{array}$ & $\begin{array}{c}48 \\
(21) \\
{[N=8,206]} \\
\{530\}\end{array}$ & $\begin{array}{c}76 \\
(28) \\
{[N=5,631]} \\
\{507\}\end{array}$ & $\begin{array}{c}59 \\
(25) \\
{[N=5,519]} \\
\{513\}\end{array}$ & $\begin{array}{c}0.022 \\
(0.011) \\
{[\mathrm{N}=8,653]} \\
\{0.191\}\end{array}$ & $\begin{array}{c}0.027 \\
(0.013) \\
{[\mathrm{N}=5,875]} \\
\{0.186\}\end{array}$ \\
\hline $\begin{array}{l}\text { High School } \\
\text { Dropout }\end{array}$ & $\begin{array}{c}49 \\
(44) \\
{[N=2,242]} \\
\{426\}\end{array}$ & $\begin{array}{c}27 \\
(40) \\
{[N=2,207]} \\
\{432\}\end{array}$ & $\begin{array}{c}17 \\
(53) \\
{[N=1,464]} \\
\{421\}\end{array}$ & $\begin{array}{c}6 \\
(48) \\
{[N=1,435]} \\
\{429\}\end{array}$ & $\begin{array}{c}0.015 \\
(0.020) \\
{[N=2,316]} \\
\{0.160\}\end{array}$ & $\begin{array}{c}0.015 \\
(0.025) \\
{[\mathrm{N}=1,533]} \\
\{0.163\}\end{array}$ \\
\hline $\begin{array}{l}\text { High School } \\
\text { Degree }\end{array}$ & $\begin{array}{c}120 \\
(39) \\
{[N=3,056]} \\
\{507\}\end{array}$ & $\begin{array}{c}99 \\
(37) \\
{[N=3,025]} \\
\{511\}\end{array}$ & $\begin{array}{c}141 \\
(45) \\
{[N=2,102]} \\
\{494\}\end{array}$ & $\begin{array}{c}129 \\
(42) \\
{[N=2,061]} \\
\{500\}\end{array}$ & $\begin{array}{c}0.033 \\
(0.018) \\
{[N=3,146]} \\
\{0.178\}\end{array}$ & $\begin{array}{c}0.039 \\
(0.021) \\
{[N=2,177]} \\
\{0.170\}\end{array}$ \\
\hline Some College & $\begin{array}{c}21 \\
(52) \\
{[N=1,441]} \\
\{531\}\end{array}$ & $\begin{array}{c}25 \\
(48) \\
{[N=1,430]} \\
\{535\}\end{array}$ & $\begin{array}{c}-5 \\
(67) \\
{[N=972]} \\
\{509\}\end{array}$ & $\begin{array}{c}28 \\
(56) \\
{[N=953]} \\
\{516\}\end{array}$ & $\begin{array}{c}0.007 \\
(0.026) \\
{[N=1,509]} \\
\{0.194\}\end{array}$ & $\begin{array}{c}0.014 \\
(0.033) \\
{[\mathrm{N}=1,031]} \\
\{0.185\}\end{array}$ \\
\hline College Degree & $\begin{array}{c}57 \\
(54) \\
{[N=1,611]} \\
\{664\}\end{array}$ & $\begin{array}{c}13 \\
(47) \\
{[N=1,581]} \\
\{676\}\end{array}$ & $\begin{array}{c}122 \\
(66) \\
{[N=1,084]} \\
\{643\}\end{array}$ & $\begin{array}{c}47 \\
(56) \\
{[N=1,063]} \\
\{652\}\end{array}$ & $\begin{array}{c}0.031 \\
(0.025) \\
{[\mathrm{N}=1,665]} \\
\{0.252\}\end{array}$ & $\begin{array}{c}0.042 \\
(0.031) \\
{[\mathrm{N}=1,125]} \\
\{0.244\}\end{array}$ \\
\hline $\begin{array}{l}\text { Periodicity of } \\
\text { Differences }\end{array}$ & 2-Year & 2-Year & 4-Year & 4-Year & 2-Year & 4-Year \\
\hline $\begin{array}{l}\text { Year-of-Birth } \\
\text { Effects? }\end{array}$ & Yes & Yes & Yes & Yes & Yes & Yes \\
\hline $\begin{array}{l}\text { Trimmed } \\
\text { Sample? }\end{array}$ & No & Yes & No & Yes & No & No \\
\hline
\end{tabular}


Table 7. Parameter Estimates by Education Group of the Impact of the Repeal of the Retirement Earnings Test on Labor Force Participation of Men Aged 6272, Based on the 1996-2004 Waves of the HRS, Standard Errors in Parentheses, Sample Size in Square Brackets, Sample Means of the Participation Measures in Curly Brackets

\begin{tabular}{|c|c|c|c|c|}
\hline & (1) & (2) & (3) & (4) \\
\hline $\begin{array}{l}\text { Education } \\
\text { Group }\end{array}$ & \multicolumn{2}{|c|}{ Any Work for Pay } & \multicolumn{2}{|c|}{ Retired } \\
\hline All & $\begin{array}{c}0.014 \\
(0.013) \\
{[\mathrm{N}=8,631]} \\
\{0.309\}\end{array}$ & $\begin{array}{c}0.018 \\
(0.015) \\
{[\mathrm{N}=5,871]} \\
\{0.299\}\end{array}$ & $\begin{array}{c}-0.001 \\
(0.014) \\
{[\mathrm{N}=8,653]} \\
\{0.639\}\end{array}$ & $\begin{array}{c}-0.007 \\
(0.016) \\
{[N=5,875]} \\
\{0.650\}\end{array}$ \\
\hline $\begin{array}{l}\text { High School } \\
\text { Dropout }\end{array}$ & $\begin{array}{c}0.002 \\
(0.023) \\
{[N=2,311]} \\
\{0.254\}\end{array}$ & $\begin{array}{c}-0.022 \\
(0.026) \\
{[N=1,533]} \\
\{0.248\}\end{array}$ & $\begin{array}{c}0.039 \\
(0.029) \\
{[N=2,316]} \\
\{0.652\}\end{array}$ & $\begin{array}{c}0.059 \\
(0.034) \\
{[N=1,533]} \\
\{0.658\}\end{array}$ \\
\hline $\begin{array}{l}\text { High School } \\
\text { Degree }\end{array}$ & $\begin{array}{c}0.026 \\
(0.022) \\
{[N=3,317]} \\
\{0.303\}\end{array}$ & $\begin{array}{c}0.039 \\
(0.026) \\
{[N=2,174]} \\
\{0.295\}\end{array}$ & $\begin{array}{c}-0.015 \\
(0.023) \\
{[N=3,146]} \\
\{0.657\}\end{array}$ & $\begin{array}{c}-0.023 \\
(0.028) \\
{[N=2,177]} \\
\{0.666\}\end{array}$ \\
\hline Some College & $\begin{array}{c}0.008 \\
(0.030) \\
{[N=1,505]} \\
\{0.325\}\end{array}$ & $\begin{array}{c}0.026 \\
(0.035) \\
{[N=1,030]} \\
\{0.316\}\end{array}$ & $\begin{array}{c}-0.020 \\
(0.031) \\
{[N=1,509]} \\
\{0.635\}\end{array}$ & $\begin{array}{c}-0.053 \\
(0.037) \\
{[N=1,031]} \\
\{0.649\}\end{array}$ \\
\hline College Degree & $\begin{array}{c}0.025 \\
(0.028) \\
{[N=1,661]} \\
\{0.382\}\end{array}$ & $\begin{array}{c}0.032 \\
(0.033) \\
{[N=1,125]} \\
\{0.364\}\end{array}$ & $\begin{array}{c}-0.021 \\
(0.028) \\
{[N=1,665]} \\
\{0.593\}\end{array}$ & $\begin{array}{c}-0.034 \\
(0.033) \\
{[\mathrm{N}=1,125]} \\
\{0.613\}\end{array}$ \\
\hline $\begin{array}{l}\text { Periodicity of } \\
\text { Differences }\end{array}$ & 2-Year & 4-Year & 2-Year & 4-Year \\
\hline $\begin{array}{l}\text { Year-of-Birth } \\
\text { Effects? }\end{array}$ & Yes & Yes & Yes & Yes \\
\hline $\begin{array}{l}\text { Trimmed } \\
\text { Sample? }\end{array}$ & No & No & No & No \\
\hline
\end{tabular}


Table 8. Parameter Estimates by Education Group of the Impact of the Repeal of the Retirement Earnings Test on Self-Reported Health Status of Men Aged 62-72, Based on the 1996-2004 Waves of the HRS, Standard Errors in Parentheses, Sample Size in Square Brackets, Sample Means of Health Status Measures in Curly Brackets

\begin{tabular}{|c|c|c|c|c|}
\hline & (1) & (2) & (3) & (4) \\
\hline $\begin{array}{l}\text { Education } \\
\text { Group }\end{array}$ & Says Health & imits Work & \multicolumn{2}{|c|}{$\begin{array}{l}\text { Says in Fair or Poor } \\
\text { Health }\end{array}$} \\
\hline All & $\begin{array}{c}-0.025 \\
(0.015) \\
{[\mathrm{N}=7,903]} \\
\{0.284\}\end{array}$ & $\begin{array}{c}-0.037 \\
(0.018) \\
{[N=5,219]} \\
\{0.276\}\end{array}$ & $\begin{array}{c}0.004 \\
(0.014) \\
{[\mathrm{N}=8,653]} \\
\{0.292\}\end{array}$ & $\begin{array}{c}0.008 \\
(0.017) \\
{[\mathrm{N}=5,875]} \\
\{0.290\}\end{array}$ \\
\hline $\begin{array}{l}\text { High School } \\
\text { Dropout }\end{array}$ & $\begin{array}{c}-0.008 \\
(0.031) \\
{[\mathrm{N}=2,073]} \\
\{0.398\}\end{array}$ & $\begin{array}{c}-0.021 \\
(0.036) \\
{[N=1,316]} \\
\{0.391\}\end{array}$ & $\begin{array}{c}0.026 \\
(0.030) \\
{[N=2,316]} \\
\{0.464\}\end{array}$ & $\begin{array}{c}0.024 \\
(0.039) \\
{[N=1,533]} \\
\{0.469\}\end{array}$ \\
\hline $\begin{array}{l}\text { High School } \\
\text { Degree }\end{array}$ & $\begin{array}{c}-0.054 \\
(0.027) \\
{[\mathrm{N}=2,864]} \\
\{0.278\}\end{array}$ & $\begin{array}{c}-0.081 \\
(0.032) \\
{[N=1,928]} \\
\{0.265\}\end{array}$ & $\begin{array}{c}-0.038 \\
(0.024) \\
{[N=3,146]} \\
\{0.276\}\end{array}$ & $\begin{array}{c}-0.033 \\
(0.027) \\
{[\mathrm{N}=2,177]} \\
\{0.270\}\end{array}$ \\
\hline Some College & $\begin{array}{c}0.007 \\
(0.033) \\
{[N=1,374]} \\
\{0.261\}\end{array}$ & $\begin{array}{c}0.031 \\
(0.038) \\
{[N=918]} \\
\{0.253\}\end{array}$ & $\begin{array}{c}0.036 \\
(0.033) \\
{[\mathrm{N}=1,509]} \\
\{0.235\}\end{array}$ & $\begin{array}{c}0.055 \\
(0.039) \\
{[\mathrm{N}=1,031]} \\
\{0.230\}\end{array}$ \\
\hline College Degree & $\begin{array}{c}-0.016 \\
(0.028) \\
{[N=1,576]} \\
\{0.168\}\end{array}$ & $\begin{array}{c}-0.045 \\
(0.034) \\
{[N=1,049]} \\
\{0.173\}\end{array}$ & $\begin{array}{c}0.017 \\
(0.025) \\
{[N=1,665]} \\
\{0.135\}\end{array}$ & $\begin{array}{c}0.013 \\
(0.032) \\
{[N=1,125]} \\
\{0.138\}\end{array}$ \\
\hline $\begin{array}{l}\text { Periodicity of } \\
\text { Differences }\end{array}$ & 2-Year & 4-Year & 2-Year & 4-Year \\
\hline $\begin{array}{l}\text { Year-of-Birth } \\
\text { Effects? }\end{array}$ & Yes & Yes & Yes & Yes \\
\hline
\end{tabular}


Figure 1

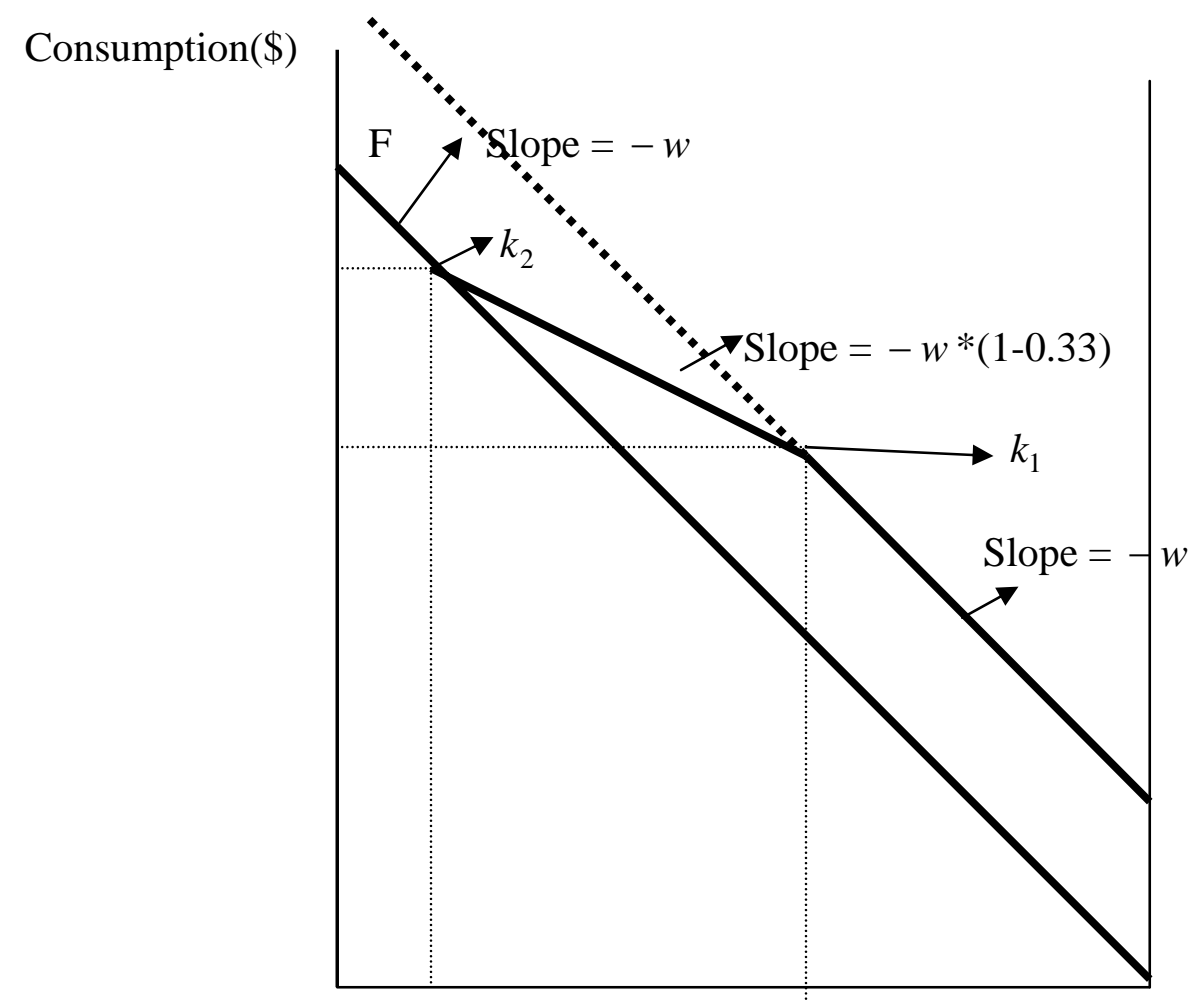

$\tilde{H}_{2} \quad \tilde{H}_{1} \quad 0 \longleftarrow$ Hours of Work 
Figure 2A. Earnings Distribution of 65-70 Year Olds Before 2000

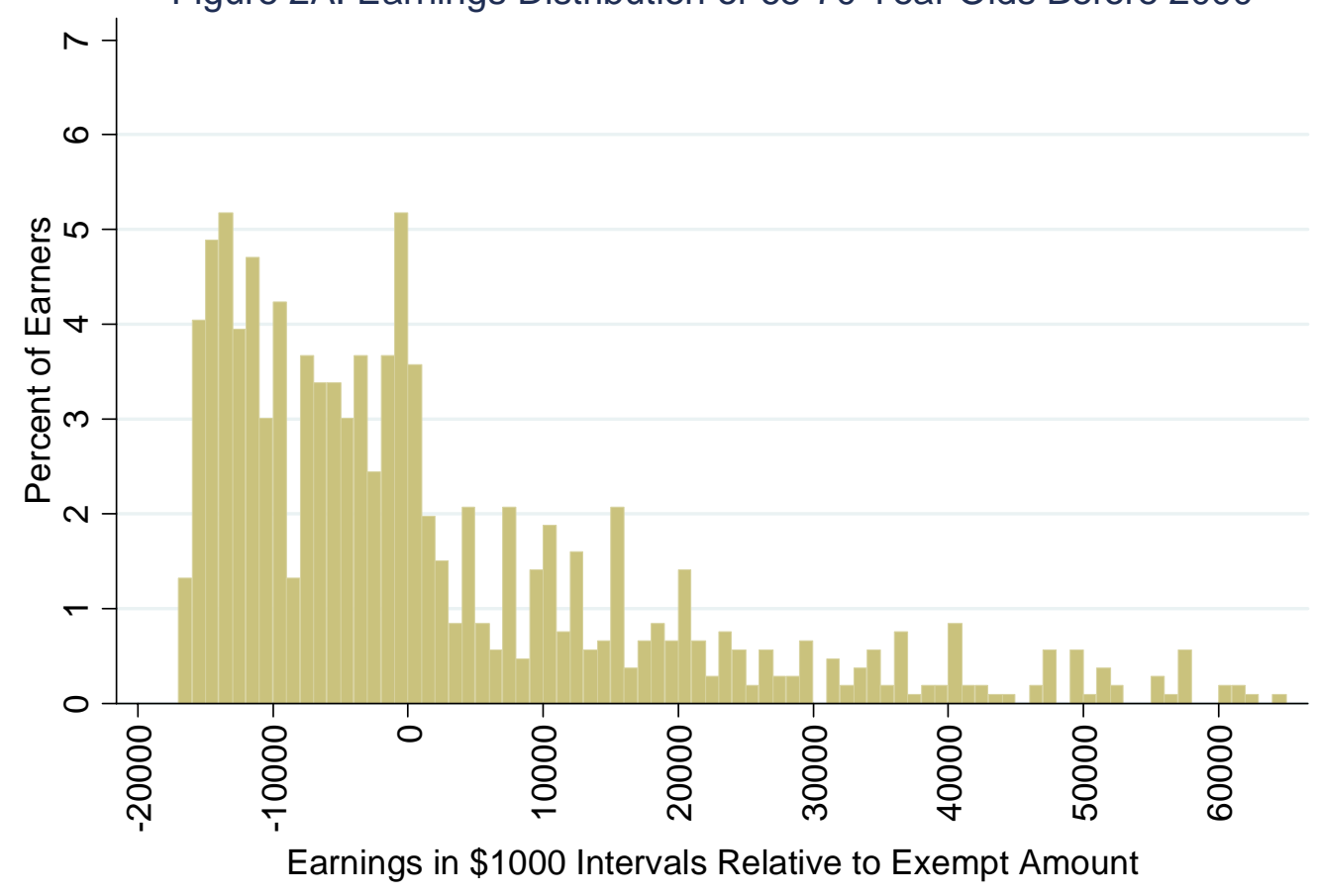

Figure 2B. Earnings Distribution of 65-70 Year Olds After 2000

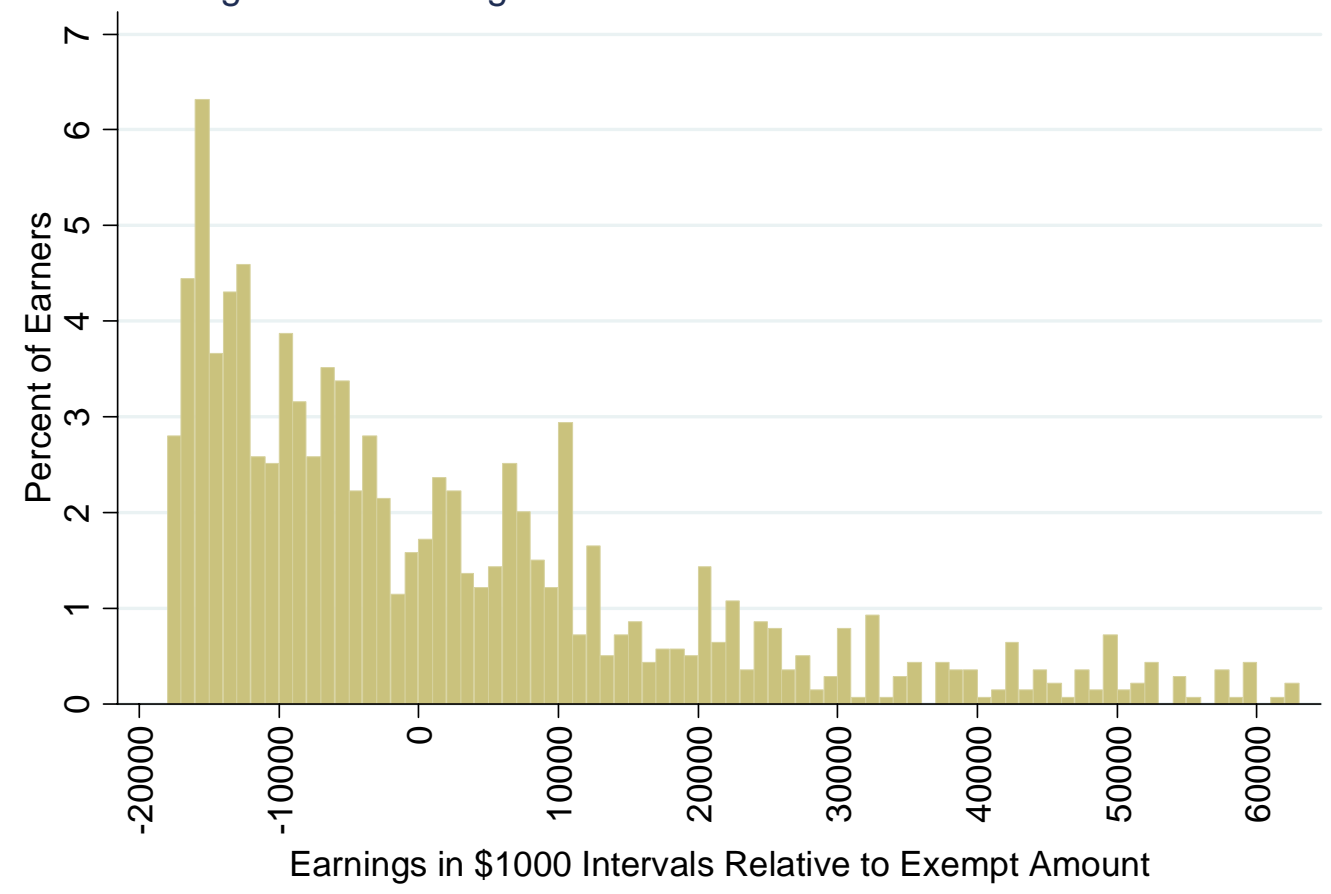


Figure 3A. Earnings Distribution of 62-64 Year Olds Before 2000

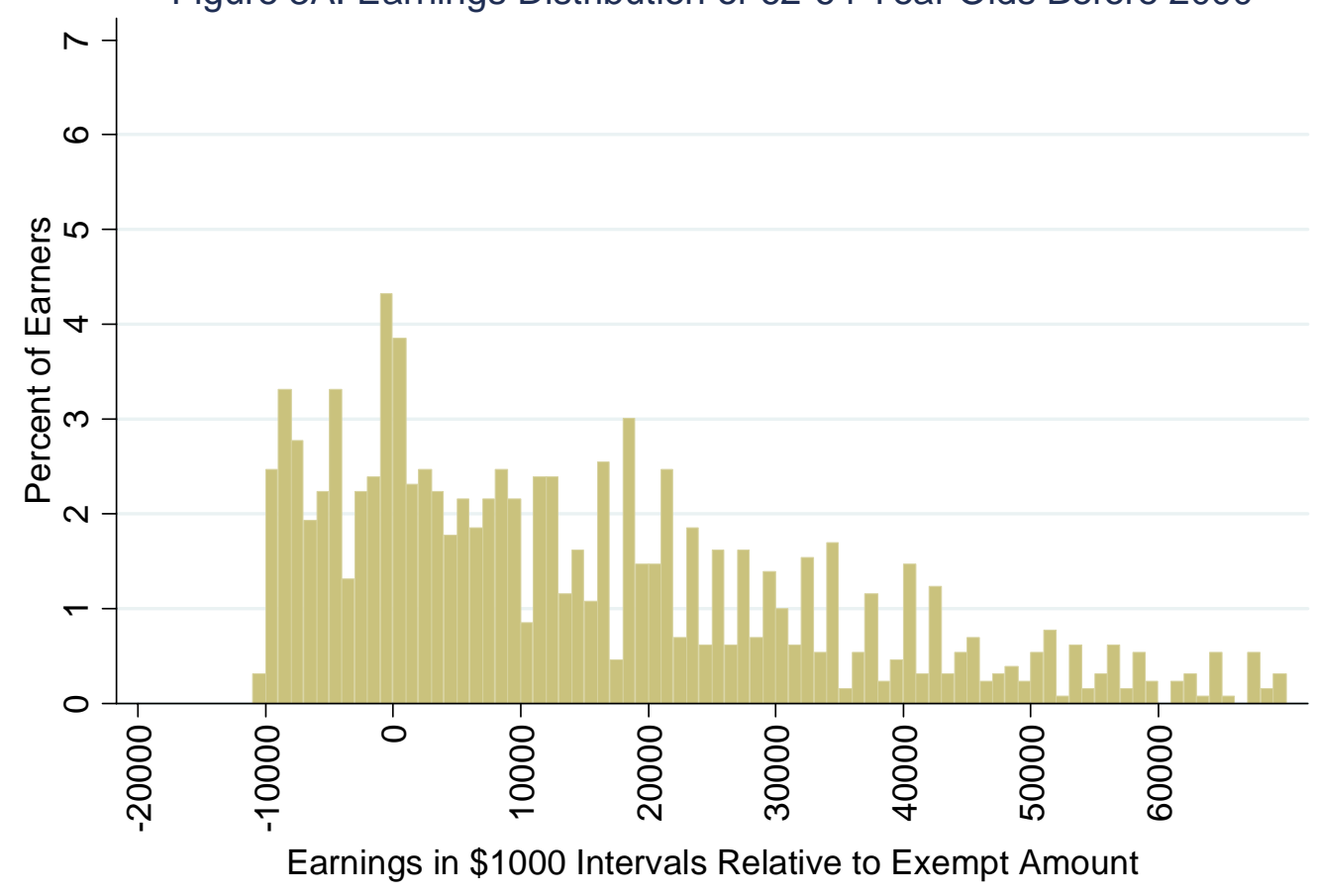

Figure 3B. Earnings Distribution of 62-64 Year Olds After 2000

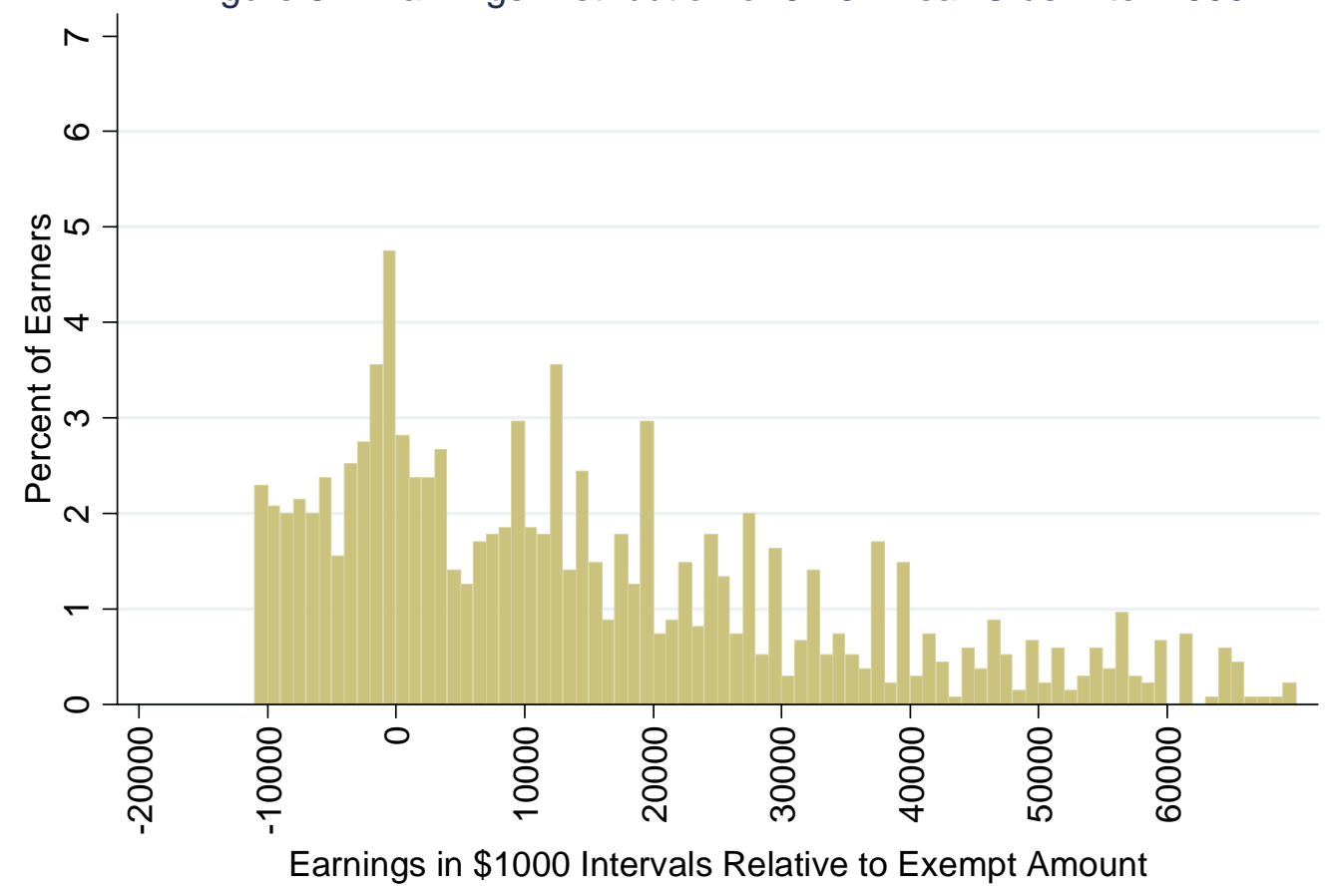




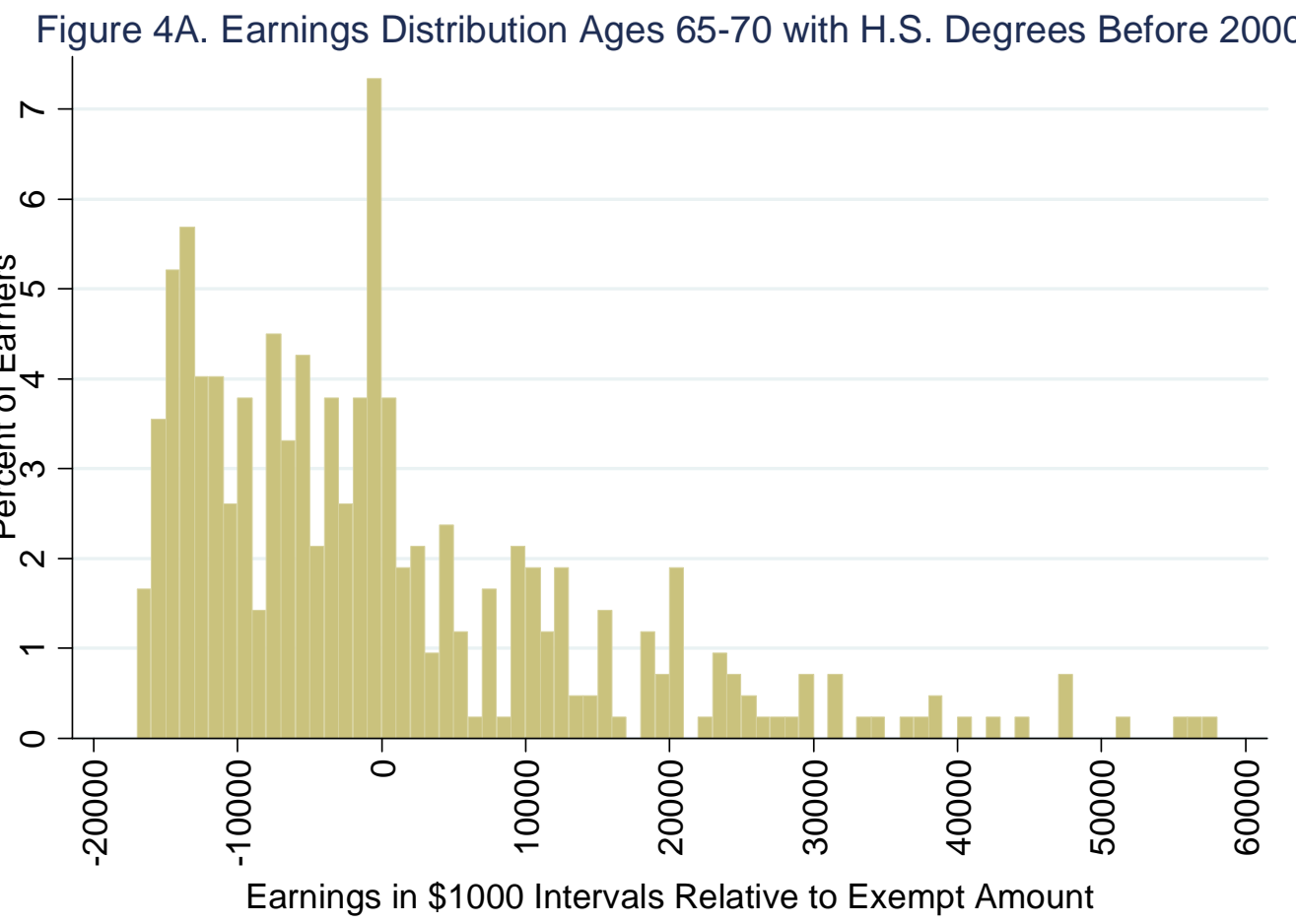

Figure 4B. Earnings Distribution Ages 65-70 with H.S. Degrees After 2000

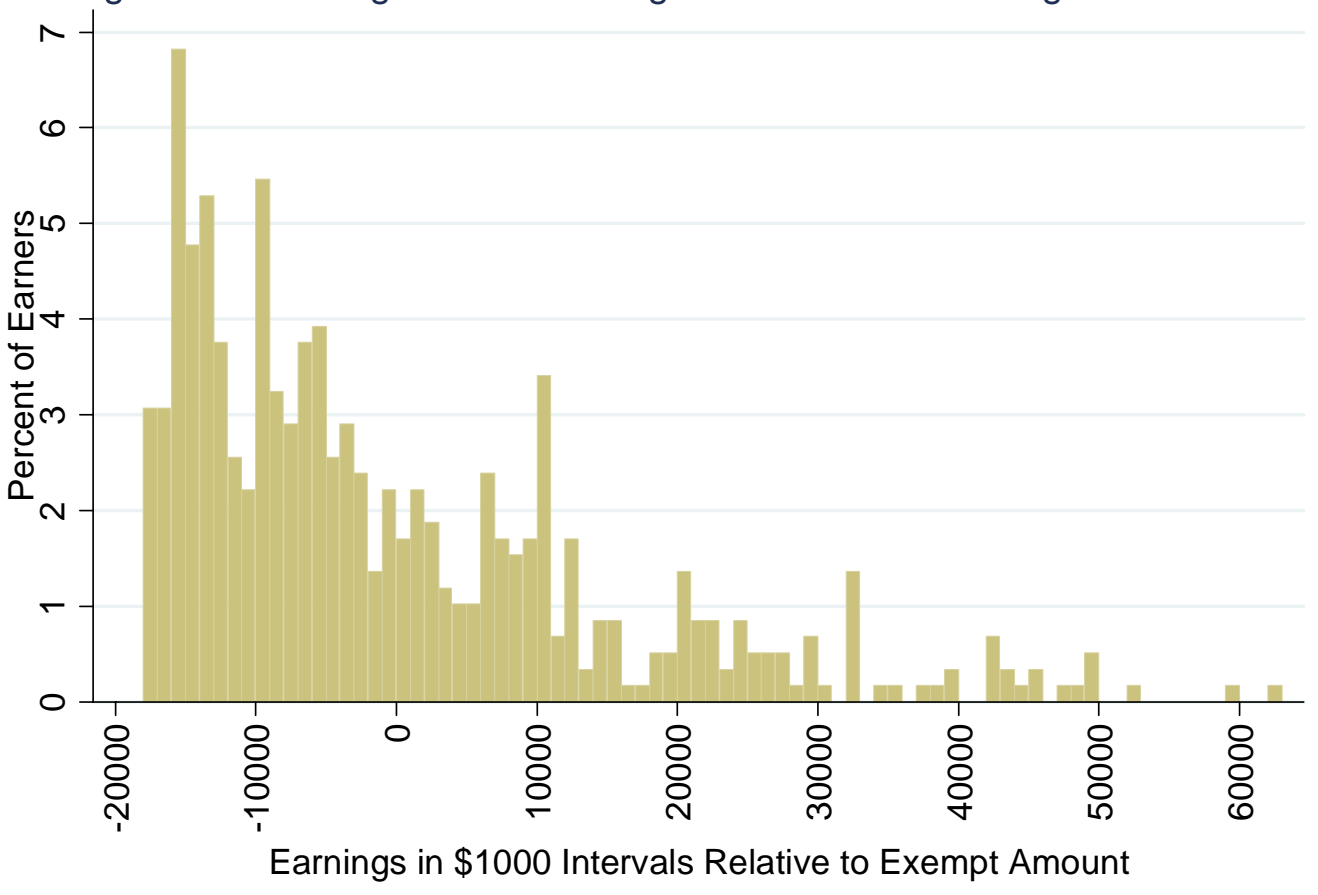


Figure 5A. Earnings Distribution Ages 65-70 Other Educ Groups Before 2000

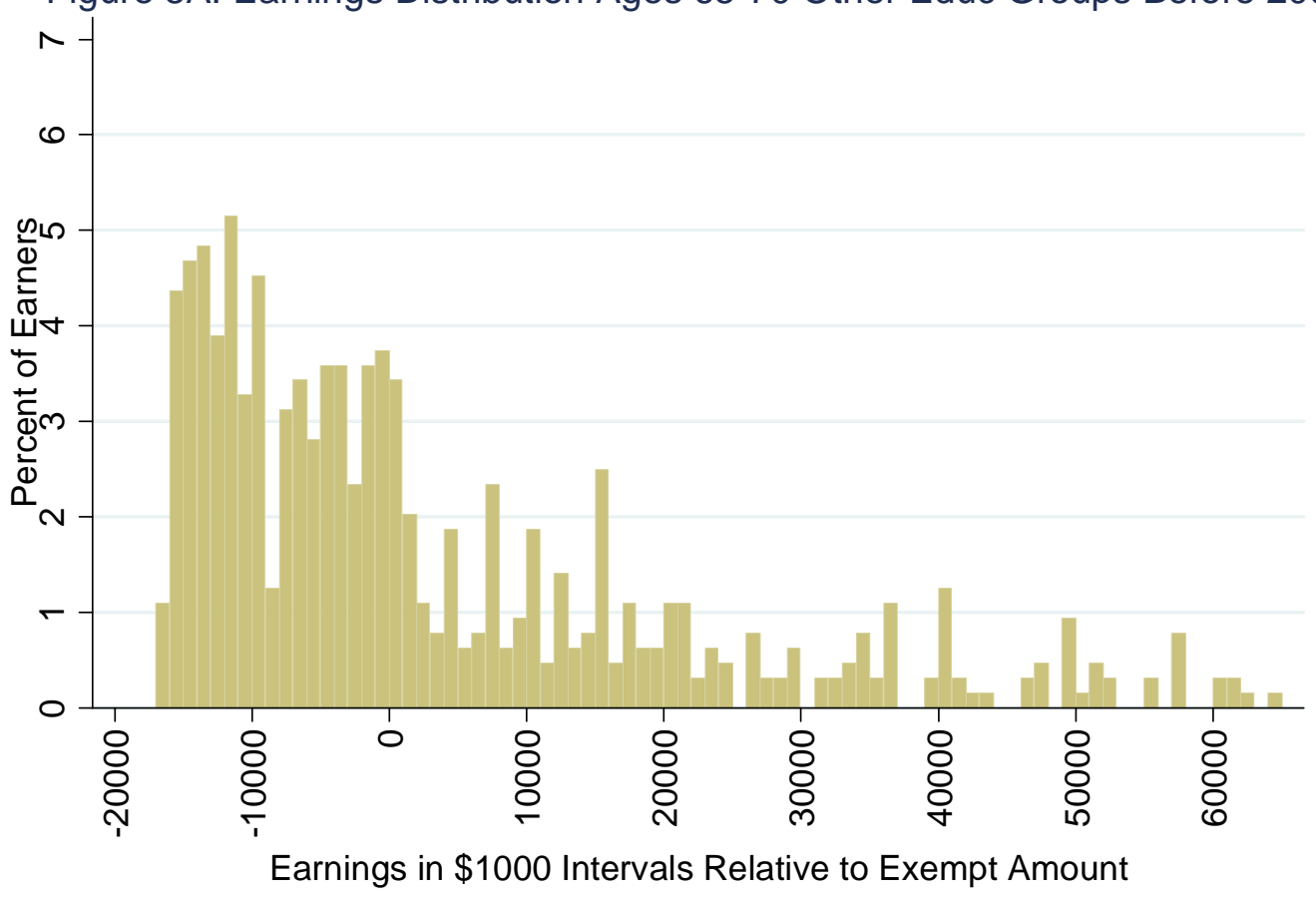

Figure 5B. Earnings Distribution Ages 65-70 Other Educ Groups After 2000

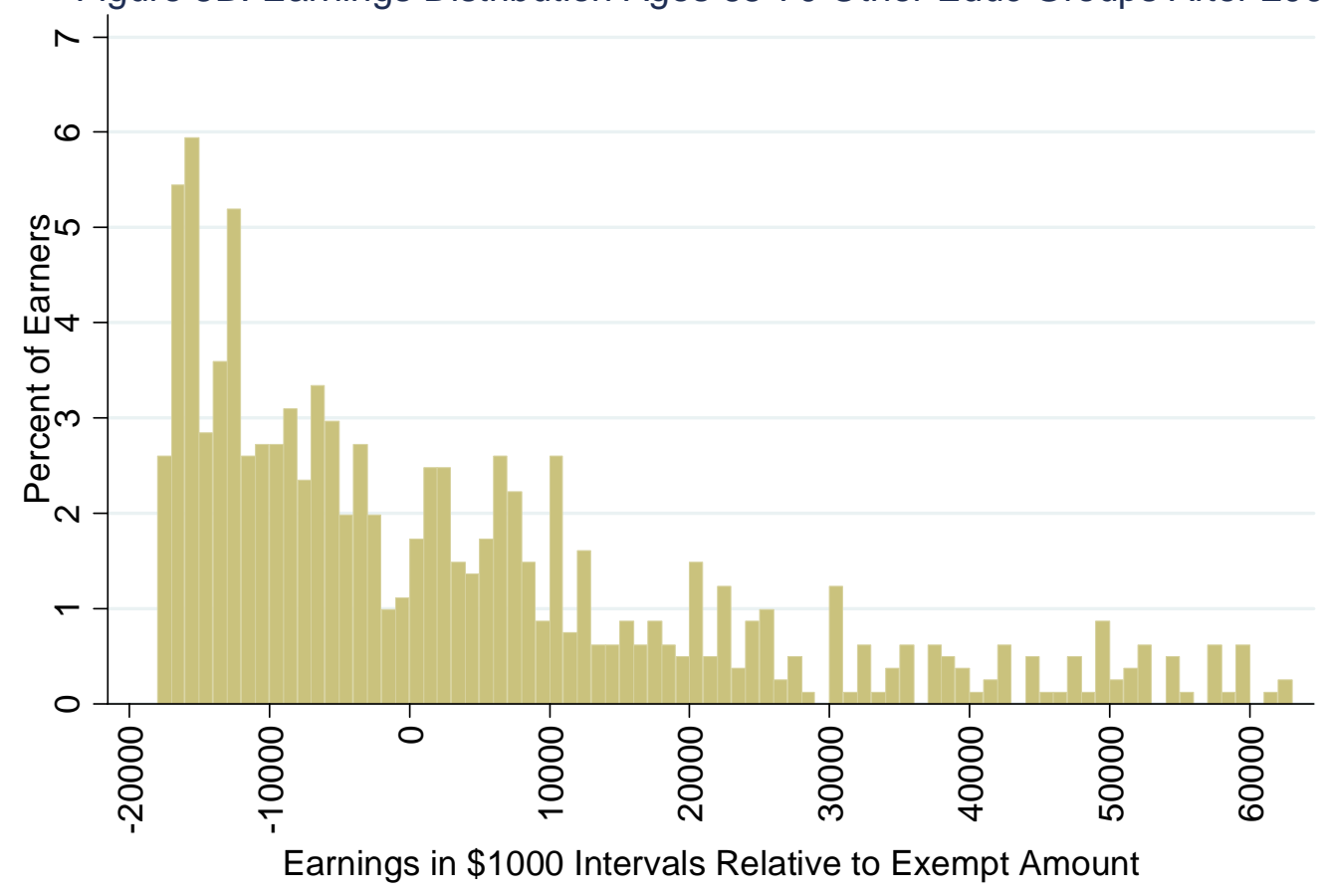




\section{RECENT WORKING PAPERS FROM THE \\ CENTER FOR RETIREMENT RESEARCH AT BOSTON COLLEGE}

Persistence in Labor Supply and the Response to the Social Security Earnings Test Leora Friedberg and Anthony Webb, December 2006

Annuitized Wealth and Consumption at Older Ages

Barbara A. Butrica and Gordon B.T. Mermin, December 2006

Risk and Reward of International Investing for U.S. Retirement Savers: Historical Evidence

Gary Burtless, December 2006

State Age Protection Laws and the Age Discrimination in Employment Act Joanna Lahey, November 2006

Age, Women, and Hiring: An Experimental Study

Joanna Lahey, November 2006

Optimal Retirement Asset Decumulation Strategies: The Impact of Housing Wealth Anthony Webb, Robert Triest, and Wei Sun, November 2006

The Impact of Aggregate Mortality Rise on Defined Benefit Pension Plans Irena Dushi, Leora Friedberg, and Anthony Webb, November 2006

Health Care Costs, Taxes, and the Retirement Decision: Conceptual Issues and Illustrative Simulations

Rudolph G. Penner and Richard W. Johnson, November 2006

Why Do Boomers Plan to Work So Long?

Gordon B.T. Mermin, Richard W. Johnson, and Dan Murphy, November 2006

Job Tenure and Pension Coverage

Alicia H. Munnell, Kelly Haverstick, and Geoffrey Sanzenbacher, October 2006

Has the Displacement of Older Workers Increased?

Alicia H. Munnell, Steven Sass, Mauricio Soto, and Natalia Zhivan, September 2006

All working papers are available on the Center for Retirement Research website

(http://www.bc.edu/crr) and can be requested by e-mail (crr@bc.edu) or phone (617-552-1762). 